\title{
STRUCTURE AND SPECIES DIVERSITY OF TRADITIONAL HOMEGARDENS IN BATTICALOA DISTRICT
}

\author{
S. Krishnal ${ }^{1}$, J. Weerahewa ${ }^{2}$
}

\begin{abstract}
A homegarden is part of a household livelihood strategy and has gained prominence as a natural asset through which sustainable use of resources, for the livelihoods of the poor, may be achieved. Despite the benefits, homegardens in the Batticaloa district have not been evaluated in-depth. This study focused on the composition, structure, diversity and different systems of homegardens in the Batticaloa district. The study was conducted in three Divisional Secretariat divisions in the district where 206 samples were collected. Results of the study revealed that average number of trees per household was 6.56. Species richness, varied from 2- 56 with the mean of 12.93. Mean Shannon index was 0.66. Two different types of systems were identified viz., Single layered and Multi layered systems. Single storied system composed only of banana or cashew or coconut trees. Only 23\% homegardens were classified as single layered system while the rest were multi layered system.
\end{abstract}

Keywords: Homegarden, Diversity, Shannon index, Evenness, Composition

\section{INTRODUCTION}

A homegarden is part of a household livelihood strategy and has gained prominence as a natural asset through which sustainable use of resources, particularly for the livelihoods of the poor, may be achieved. Homestead gardening systems provide an important contribution to sustainable agricultural production because of their potential to meet economic, social, ecological, and institutional conditions for sustainable livelihoods (Nair, 2006).

Tropical homegardens consist of an assemblage of plants, which may include trees, shrubs, vines, and herbaceous plants, growing in or adjacent to a homestead or home compound. The word "homegarden" has been used rather loosely to describe diverse practices. It is used to refer to intimate association of multipurpose trees and shrubs with annual and perennial crops and, invariably livestock within the compounds of individual houses, with the whole crop-tree-animal unit being managed by family labor (Fernandes and Nair,
1986). It is a micro-environment composed of a multi-species (annual to perennial, root crops to climbers etc), multi-storied and multipurpose garden situated close to the homestead (Quat, 1996; Watson and Eyzaguirre, 2002; Hodgkin, 2002). A home garden also refers to the traditional land use system around a homestead, where several species of plants are grown and maintained by the household members and their products are primarily intended for the family consumption. Several terms have been used to describe these garden production systems, such as "homestead garden, backyard garden, kitchen garden, agro forestry, mixed garden, garden culture, etc" (Helen Keller International, 2001; Mictchell and Hanstad, 2004). Diversity of plant species and the layered canopy of species are the most striking features of homegardens, with all homegardens generally consisting of "a herbaceous layer near the ground, a tree layer at upper levels, and intermediate layers in between" (Nair 1993).

\footnotetext{
1 Department of Agricultural Economics, Faculty of Agriculture, Eastern University, Sri Lanka.

2 Department of Agricultural Economics and Business Administration, Faculty of Agriculture, University of Peradeniya, Sri Lanka.
} 
Species diversity in tropical home garden is reported to be very high due to species having different life forms, height and canopy structure (Babu et al., 1994; Soemarwoto and Conway,1991). Distribution of species in the home garden creates a forest like multistorey structure (Singh, 1987). Structure of home gardens varies from place to place depending upon the socio-economic and ecological conditions (Soemarwoto, 1987).

Home gardens are perhaps the best-developed agroforestry system in Sri Lanka. This system of perennial cropping has been practiced for centuries. It is essentially mixed cropping with a variety of tree species that provide food, fruits, timber, medicine and spices. The significance of homegardens to rural livelihoods is well appreciated throughout the world (Fernandes and Nair, 1986; Soemarwoto, 1987; Torquebiau, 1992; Jose and Shanmugaratnam, 1993; Nair, 2006). The garden may become the principal source of household food and income during periods of stress, e.g. the preharvest lean season, harvest failure, prolonged unemployment, health or other disabilities suffered by family members or agricultural and economic disruption caused by warty as well.

Despite the above potential benefits of Homegarden, a review of literature clearly showed that there is a lack of research on plant species diversity and different systems of the homegardens in the Batticaloa District. Within this context this study aimed at analyzing the plant species structure and species diversity of homegarden in Batticaloa. Specific objectives were to identify the species composition of homegarden in Batticaloa, to analyse the species richness, diversity and evenness of homegardens, and to investigate the different systems of homegardens in Batticaloa district.

\section{METHODS AND METHODOLOGY}

\section{Study site and sampling}

Three Divisional Secretariat (D.S.) divisions were selected where comparably higher extent of homegarden were found viz., Eravurpattu, ManmunaiSouth\&Eruvilpattuand Korelapattu D. S. divisions. (Department of Census and Statistics, 2002). They rank first, second and third with the extents of $1645.5,1533.6$ and 1426.1 acres respectively. In these three D. S. divisions, eleven Grama Niladhari divisions were selected and from those, seventy, sixty seven and sixty nine samples were collected respectively from each Divisional Secretariat divisions by personal visit and altogether 206 samples were collected. The unit of analysis is household homegardens for tree inventory.

Data on names of crops, DBH, height (m), and growth stages were also obtained through tree inventory data.

\section{Data analysis}

\section{Species composition of Homegardens in Batticaloa}

Most common homegarden tree species were identified and their frequency of occurrence and the average yield per annum were calculated.

\section{Diversity and systems of homegardens}

To determine the species diversity, species richness and species evenness were calculated. By using Shannon diversity index different systems of homegardens in the surveyed area were identified. Shannon Wiener index and Evenness measure (E), which are commonly used tools for these purposes (Pielou, 1969: Magurran, 1988; Huston, 1995) were computed. 
Shannon Diversity Index

$\mathrm{H}={ }^{\mathrm{s}} \sum_{\mathrm{i}=1}-\left(\mathrm{P}_{\mathrm{i}} * \ln \mathrm{P}_{\mathrm{i}}\right)$

Where, $\mathrm{H}=$ Shannon diversity index

$\mathrm{P}_{\mathrm{i}}=$ fraction of the crop area composed of species i.

$\mathrm{S}=$ numbers of species encountered

$\sum=$ sum from species 1 to species $\mathrm{S}$

The measure of Evenness (E) is the ratio of observed diversity to maximum diversity and it is calculated as,

$\mathrm{E}=\mathrm{H} / \mathrm{Hmax}$,

$\mathrm{E}=\mathrm{H} / \operatorname{lnS}$ (Magurran, 1988)

\section{Classification of systems in Homegarden}

By using the Shannon - Weiner index for different homegardens, the different systems were identified. The index having the value of 0 and with single canopy was considered as single layered system. The Shannon index of 0.1 and above and having more than one canopy were considered as multi layered systems.

Profile diagram of home garden was constructed according to appearance and height of the plant species.

\section{RESULTS AND DISCUSSION}

Species composition of Homegardens in Batticaloa

The most common tree species recorded during this survey were listed in Table 01 . They include coconut, cashew, mango and banana. Average number of trees per household was 6.56. An average of 3.02 coconut trees per household was recorded followed by 1.39 banana trees per household. One coconut tree yielded an average of 111.5 nuts in a year. A mean number of 755 fruits per tree were yielded in cashew trees, but a year round production was not observed in cashew plants.

\section{Species richness, diversity and evenness}

Species richness, varied from 2- 56 with the mean of 12.93. The abundance of plants in these gardens is generally uneven because some species, particularly coconut are more dominant.

Shannon Index gives a measure of both species numbers and the evenness of their abundance. The results revealed that Shannon index progressed from 0 to 1.79 with the mean and standard deviation of 0.66 and 0.44 respectively. The high diversity in some homegardens could be the result of selection of species by the owners with utility of the specific products as the main criterion. Shannon value of 0 means there is only one species in that homegarden. The index is increased either by having additional unique species, or by having greater species evenness.

An evenness value of 0 was observed in $23 \%$ of homegardens where coconut or cashew or banana alone shared $100 \%$ of the crop area. A community dominated by one or two species is considered to be less diverse than one in which several different species have a similar abundance. The mean evenness value of 0.615 for the sampled area indicated that evenness in abundance of the species is $61.5 \%$ of what would have been under uniform or even distribution.

Results also indicated that there exists a large variation in diversity and evenness among homegardens. Plant species richness and diversity of plants varied considerably in the areas and hence in addition to the integrated multi-storey gardens, patches of less complex and monoculture composing of coconuts or bananas or cashews were also found. This variation is likely to affect the long-term sustainability of the systems because studies indicate that the diversity and complex 
structure of homegardens is responsible for positive agroecosystem functions (Jensen, 1993). Okafor and Fernandes (1987) have also reported that replacement of compound homegardens with monocropping in Nigeria has resulted in severe soil degradation and poor yields. It is also argued that intensification could increase production but in many cases it reduces output stability and resource use efficiency and enhances over-exploitation of the resource base (Almekinders et al., 1995). But, why there is a variation in the diversity and composition of plants different in these agro ecologically similar areas, or why do farmers alter the diversity and composition of crops in their farms? Transport facilities, soil characters, access to water and market facilities can be considered as some of the reasons.

Some studies also have indicated that access to markets (Wiersum, 1982; Soemarwoto and Conway, 1991), access to road (Kaya et al., 2002), altitude (Soemarwoto and Conway, 1991), and farm size (Wiersum, 1982; Jacob and Alles, 1987; Rico Gray et al, 1991) affect the diversity and composition of plants in homegardens.

\section{Classification of systems in Homegarden}

On the basis of Shannon- Weiner index and number of canopies, two different systems were identified viz., Single layered and multi layered cropping systems (Table 02)

Table 01: Most common homegarden tree species in Batticaloa and their frequency of occurrence

\begin{tabular}{llcc}
\hline \multicolumn{1}{c}{$\begin{array}{c}\text { Trees } \\
\text { (Generic name) }\end{array}$} & \multicolumn{1}{c}{ Scientific name } & $\begin{array}{c}\text { Average number of } \\
\text { trees per HG }\end{array}$ & $\begin{array}{c}\text { Avg. yield of tree/ } \\
\text { annum }\end{array}$ \\
\hline Coconut & Cocos nucifera & 3.02 & 111.5 nuts \\
Banana & Musa paradisiaca & 1.39 & 1 bunch \\
Cashew & Anacardium occidentale & 0.89 & 755 fruits \\
Mango & Mangifera indica & 0.51 & 325 fruits \\
Moringa & Moringa oleifera & 0.15 & 86.5 fruits \\
Palmyrah & Borassus flabellifer & 0.14 & 135 \\
Jack & Artocarpus heterophylla & 0.14 & 8 fruits \\
Pomegranate & Punica granatum & 0.07 & 9 fruits \\
Orange & Citrus sinensis & 0.06 & 23 fruits \\
Arecanut & Areca catechu & 0.05 & 201 nuts \\
Guava & Psidium guajava & 0.03 & 15 fruits \\
Neem & Azadirachta indica & 0.02 & - \\
Lime & Citrus aurantifolia & 0.02 & 16 fruits \\
Anona & Annona muricata & 0.01 & 9 fruits \\
Karapincha & Murraya koenigii & 0.01 & - \\
Lemon & Citrus limon & 0.01 & 12 fruits \\
\hline
\end{tabular}

Table 02: Mean Shannon and Evenness values

\begin{tabular}{ccc}
\hline Systems & Mean Shannon index & Mean Evenness value \\
\hline Single layered & 0 & 0 \\
Multi layered & 0.86 & 0.79 \\
\hline
\end{tabular}


Single storied system composed of banana or cashew or coconut trees with the mean height of $4 \mathrm{~m}, 8.04 \mathrm{~m}$ and $9.09 \mathrm{~m}$ respectively. In the study only one stratum could be seen. Only $23 \%$ homegardens were classified as single layered system (Figure 01). In the multi system the lower layer dominated by different vegetable crops such as Solanum melongina, Capsicum annum, Vigna unguiculata, Abelmoschus esculentus, Momordica Charantia, Manihot esculenta and so on (less than $1 \mathrm{~m}$ height), the second layer composed of fruit trees such as Annona muricata, Citrus aurantifolia, Citrus limon, Musa paradisiaca, Citrus sinensis, Punica granatum and trees such as Murraya koenigii and Moringa oleifera (2- $6 \mathrm{~m}$ in height). Mangifera indiaca, Anacardium occidentale, Psidium guajava, Carica papaya and Azadirachta indica ( $8-10 \mathrm{~m}$ in height) constitute the third layer. The fourth storey made up of Areca catechu, Artocarpus heterophylla and Borassus flabellifer (10$15 \mathrm{~m}$ in height). Cocos nucifera (15$20 \mathrm{~m})$ constitutes the top most layers. But all the homegardens do not consist of all these layers. It may vary from 2- 5. Michon (1983) reported, from an analysis of the structure of the Pekarangan in the Citarum watershed in West Java, a five-layered canopy structure. The multi-layered, forest-like vegetation structure of homegardens contributes substantially to the ecological sustainability of the village ecosystems (Kehlenbeck and Maass 2004).

Based on these a schematic presentation was developed showing the vertical canopy zonation of multi storied system in Batticaloa and is presented in Figure 02.

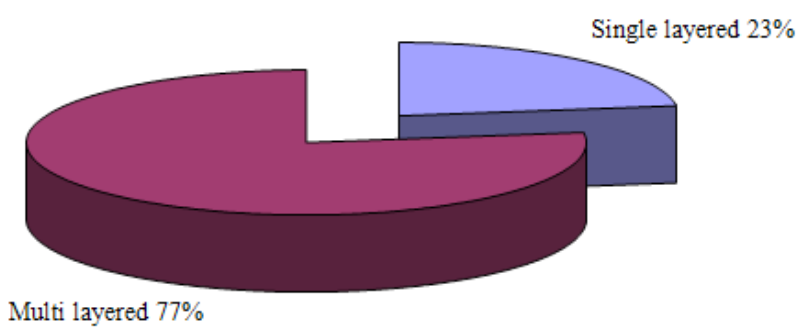

Figure 1: Frequency of different systems in study area

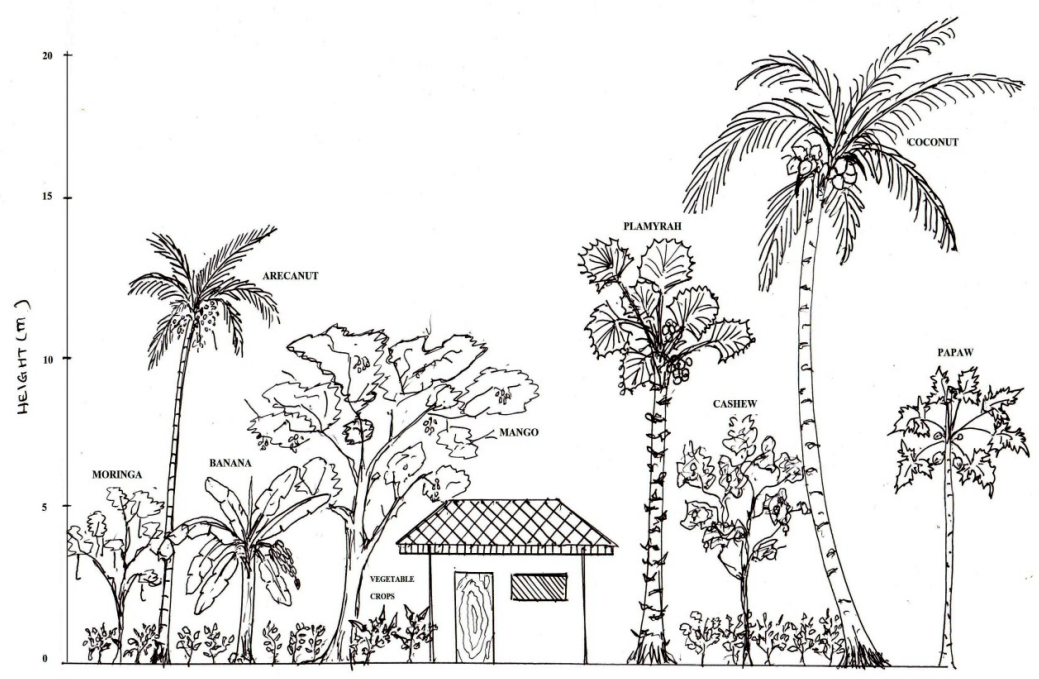

Figure 2: Schematic presentation of the vertical canopy zonation of multi storied system in Batticaloa Homegarden 


\section{CONCLUSIONS}

This study set out to investigate the composition, structure, diversity of plant species and different systems of homegardens in Batticaloa district. The study was carried out in three Divisional Secretariat divisions. The study revealed that the most common tree species recorded during this survey were coconut, cashew, mango and banana. It was found that there were two different systems of homegardens on the basis Shannon value and number of canopies. Shannon value of 0 yielded the single layered system which comprised only banana or cashew or coconut. $77 \%$ of the homegardens were Multi storied system composed of different tree combinations, but tree species were not homogenous among homegardens.

\section{REFERENCES}

Almekinders, C. J. M, Fresco LO and Struik P. C. (1995). The need to study and manage variation in agro-ecosystems. Netherlands Journal of Agricultural Science 43: 127-142.

Babu, S.C.D.N. Ng'ong'ola, and G.B. Mthindi (1994). Developing decentralized capacity for development policy analysis: Lessons for agricultural development from food security and nutrition monitoring in Malawi

Department of Census and Statistics of Sri Lanka, 2002 (www. statistics. gov. 1k)

Fernandes, E.C.M. and Nair, P.K.R. (1986). An evaluation of the structure and function of tropical homegardens. Agricultural Systems 21:279-310

Helen Keller International/Asia-Pacific (2001) Homestead Food Production - A Strategy to Combat Malnutrition and Poverty. Helen Keller International: Jakarta, Indonesia.

Hodgkin, T. (2002). Home gardens and the maintenance of genetic diversity. In: Watson JW and Eyzaguiree PB. Editors. Homegardens and in situ conservation of plant genetic resources in farming systems, 17-19 July 2001, Witzenhausen, Germany IPGRI, Rome, pp. 14- 18

Huston, M.A. (1995). Biological diversity: The coexistence of species on changing landscapes. Cambridge University press.

Jacob, V.J. and Alles, W.S. (1987). Kandyan Gardens of Srilanka. Agroforestry Systems 5:123137

Jensen M1993 Productivity and nutrient cycling of a Javanese homegarden. Agroforestry Systems 24: 187-201. 
Jose, D. and Shanmugaratnam, N. (1993). Traditional homegardens of Kerala: a sustainable human ecosystem. Agroforestry Systems 24, pp. 203-213.

Kaya, M., Kammesheidt, L. and Weidelt, H.J.( 2002). The forest garden system of Saparua island, central Maluku, Indonesia, and its role in maintaining tree species diversity. Agroforestry Systems 54: 225-234

Kehlenbeck, K., Maass, B.L . (2004). Crop diversity and classification of homegardens in Central Sulawesi, Indonesia. Agroforestry Systems, 63: 53-62.

Magurran, A. E. (1988). Ecological diversity and its measurement. Princeton, NJ: Princeton University Press

Michon, G.(1983). Village-forest-gardens in West Java. In: Huxley, P.A. (ed.), Plant Research and Agroforestry, pp. 13-24. ICRAF, Nairobi, Kenya

Mitchel, R. and T. Hanstad. (2004). Small homegarden plots and rural livelihoods for the poor. Rural Development Institute (RDI), USA: pp 44

Nair, P. K. R. (1993). An introduction to agroforestry. Kluwer academic publishers.

Nair, P. K. R. (2006). An Introduction to Agroforestry, KLUWER Acdemic Publishers, University of Florida, Gainesville, Florida University Press, Princeton, NJ.

Okafor, J.C. and Fernandes, E.C.M. (1987). The compound farms of southeastern Nigeria: A predominant agroforestry homegarden system with crops and small livestock. Agroforestry Systems. 5: 153-168

Pielou, E.C. (1969). An Introduction to Mathematical Ecology. Wiley, New York

Quat Nguyen Xuan (1996). Home garden systems in Vietnam. In: Biological diversity: An overview

Rico-Gray V, Chemas, A. and Mandujano, S. (1991). Uses of tropical deciduous forest species by the Yucatecan Maya. Agroforestry Systems 14: 149-161

Singh, G.B. 1987. Agroforestry in the Indian sub- continent: past, present and future. pp. 117140. In: H.A. Steppler \& P.K.R. Nair (eds.) Agroforestry: A Decade of Development. ICRAF, Nairobi, Kenya.

Soemarwoto, O. (1987). Homegardens: A traditional agroforestry system with a promising future. In: Steppler, H.A. and Nair, P.K.R. (eds.), Agroforestry: A Decade of Development, pp. 157-170, ICRAF, Nairobi, Kenya

Soemarwoto, O. and G.R. Conway (1991). The Javanese homegarden. Journal of Farming Systems Research-Extension 2(3): 95-117

Torquebiau, E. (1992). Are tropical agroforestry home gardens sustainable?. Agric Ecosyst Environ 41 , pp. 189-20

Wiersum, K.F. (1982). Tree gardening and Taungya on Java: examples of agroforestry techniques in the humid tropics. Agroforestry Systems 1: 53-70 
Watson, J.W. and P.B. Eyzaguirre, (2002). P roceedings of the Second International Home Gardens Workshop: Contribution of home gardens to in situ conservation of plant genetic resources in farming systems, 17-19 July 2001, Witzenhausen, Federal Republic of Germany. International Plant Genetic Resources Institute, Rome. 